\title{
Analysis of Cementum Layers in Archaeological Material
}

\author{
Michaela Huffman ${ }^{1}$ and Daniel Antoine ${ }^{2}$ \\ ${ }^{1}$ Department of Anthropology, Ohio State University, 4034 Smith Laboratory, 174 West 18th Street, Columbus, Ohio \\ 43210 \\ ${ }^{2}$ The British Museum, Great Russell Street London, United Kingdom WC1B 3DG
}

\begin{abstract}
The aim of this study was to assess the utility of cementum layers for estimating age at death of remains from an archaeological site. Variability in cementum layer counts due to interobserver error and variation among dental regions were analyzed. Interobserver error was later incorporated into age ranges based on counts of cementum layers and compared with age estimates derived from the skeleton. The layers were counted, using 9 teeth from 3 individuals, and the eruption age of the tooth was summed with the average layer count to achieve an estimated age. The research indicates that the assessment of archaeological dental cementum layers
\end{abstract}

Dental cementum is calcified tissue that covers the dentine and helps support the teeth within the periodontium. Cementoblasts are cementum-forming cells that are interposed between bundles of the periodontal ligament fibers, while cementocytes are cementoblasts that have been incorporated into the matrix (Lieberman, 1994). The cementum-dentine junction (CDJ) defines where the dental cementum incremental layers begin (Jones, 1981). Cementum is composed of incremental layers that follow the circumference of the roots and thickens with age. There have been correlations between the number of cement layers in humans cement and the number of years that have elapsed since root formation, indicating these layers are supposed to be deposited annually (Hillson, 1986). Generally, cementum layers can be viewed using transmitted light microscopy, scanning electron microscope (SEM), or polarized light microscopy (Hillson, 1986, 1996). The section thickness to view cementum layers properly is debated, and suggestions range from 10 to $100 \mu \mathrm{m}$ (Naylor et al., 1985; Maat et al,. 2006; Stamfelj et al., 2008).

There is a large body of research pertaining to the assessment of age-at-death estimates in humans based on the number of dental cementum layers (Charles et al., 1986; Condon et al., 1986; Kvaal and Solheim, 1995; Hillson, 1986; Wittwer-Backofen et al., 2004; Renz and

Editor's note: Ms. Huffman's paper was awarded "First Prize" for 2010 in the Albert A. Dahlberg student research competition sponsored by the Dental Anthropology Association. has a relatively high interobserver error. The cementum layer aging method resulted in large age ranges and did not correspond with age ranges from skeletal techniques. Chemical diagenetic processes can affect the observation and count of cementum layers by obscuring bands and/ or creating additional bands. The variables that affected observability of cementum layers were: high interobserver error, discrepancy of readability of root regions, and large age ranges using the cementum layer technique that exceeded age ranges derived from other, skeletal methods Dental Anthropology 2010;23(3):67-73.

Radlanksi 2006). The majority of these studies were developed using modern human teeth (Bosshardt and Schroeder, 1991; Maat et al., 2006; Wedel, 2007; Stamfelj et al., 2008). Cementum layers were first examined in marine and hibernating land mammals, migratory ungulates and their dependent carnivores (Morris, 1978; Perrin and Myrick, 1980; Hillson, 1986), and the method is useful for determining chronological age. Stott et al. (1982) evaluated the accuracy of age estimation using cementum layers in humans, and found a good correlation between the number of layers and the age-at-death in years.

Fewer studies have applied or tested this method on archaeological material (Beasley et al., 1992; Lieberman, 1994; Klevezal and Shishlina, 2001; Jankauskas et al., 2001; Stutz, 2002; Hillson and Antoine, 2003; Maat et al., 2006; Roksandic et al., 2009). Recording such structures in archaeological teeth presents additional challenges not found in modern specimens. For instance, the integrity of dental tissue can be compromised through various diagenetic processes (Lieberman, 1994; Stutz, 2002) and, when the chronological age at death is unknown, establishing the accuracy of such methods is difficult. Despite these issues, the method has often been applied to archaeological specimens (Stutz, 2002; Maat et al., 2006; Roksandic et al., 2009). Evaluating the recordability and accuracy of cementum layers as an ageing method in

Correspondence to: Michaela Huffman, 1300 Presidential Drive, Apartment 202, Columbus, Ohio 43212

E-mail: michaela.huffman@gmail.com or huffman.636@ buckeyemail.osu.edu 
archaeological material should be carefully considered.

Previous studies have found cementum counts to be a useful method for estimating biological age in archaeological material (Beasley et al., 1992; Lieberman, 1994; Jankauskas et al., 2001; Klevezal and Shishlina, 2001; Maat et al., 2006). Many of these studies conclude that cementum layers in archaeological material should give the same results as cementum layers in modern dentitions, as long as diagenetic processes do not affect the cementum and certain preparation methods are followed (section technique, type of microscopy). The results of Roksandic et al. (2009) and Stutz (2002) suggest that cementum in archaeological teeth is affected by diagenetic processes that can-particularly when observed in transmitted light microscopy -obscure layers or create optical artifacts in the form of extra cementum layers. These processes can result in observability and counting issues. This is particularly true of transmitted light microscopy, where the observation plane requires light to pass through several tens or hundreds of microns of tissue, offering ample opportunity for the light reflecting from each cementum layer to be affected by the optical properties of the tissue (Roksandic et al., 2009).

The present study focuses on human dental cementum in archaeological material, specifically with issues of observability, area of root with highest quality of cementum, and comparison to other aging methods. Particular emphasis is placed on interobserver error, region of root correlating most closely with chronological age, and comparisons between this cementum-layer aging method and other aging techniques. Understanding the variables that affect observability of archaeological cementum layers should aid establishing a best practice when using these layers to estimate biological age of individuals.

\section{MATERIALS AND METHODS}

The specimens used were from the Farringdon Street excavation, London (1730-1849), currently housed at The

TABLE 1. Tooth types of the 9 specimens analyzed

\begin{tabular}{ll}
\hline $\begin{array}{l}\text { Specimen } \\
\text { number }\end{array}$ & Tooth type \\
\hline
\end{tabular}

FA090 1408

maxillary right canine (URC) maxillary right third premolar (URP3) mandibular right second molar (LRM2)

FA090 1519

mandibular left central incisor (LLCI) maxillary right canine (URC) maxillary right third premolar (URP3)

FA090 1116

maxillary right canine (URC) maxillary left fourth premolar (ULP4 mandibular right first molar (LRM1)
Museum of London. Three individuals of unknown age were chosen from the collection, and were aged using the Lovejoy et al. (1985) eight-phase auricular surface technique and the Suchey-Brooks (1990) six-phase pubic symphysis method. This aging method was chosen because it has been shown to give good estimates of age at death (Scheuer and Black, 2000; Bass, 2005).

Three teeth were taken from each individual for a total of 9 teeth. A tooth was only used if an antimere was present so as to preserve the integrity of the Museum of London collection. Each specimen and tooth type was chosen on the basis of preservation, the presence of its antimere, and prior use in other published studies (Table 1). Typically, incisors, canines, premolars, and molars are used to count cementum layers (Solheim, 1990; Jankauskas et al., 2001), although some studies have indicated that premolars are a more reliable age indicator (Condon et al., 1986; Charles et al., 1986; Renz et al., 1997).

Specimens were embedded in the methylmethacrylate (MM). The two-week slow curing of this resin allows it to be fully absorbed into the tooth, strengthening the cementum and allowing the integrity of the tissue to be preserved during sectioning and polishing (Hillson, 1986). Sectioning was performed as follows (adapted from Antoine 2001):

1. A Buehler Isomet Low Speed Saw with a diamond abrasive-edge blade was used for the sectioning with 1:1 distilled water: industrial methylated spirit (IMS) as the lubricant.

2. Two cuts were made. The first was taken approximately $50 \mu \mathrm{m}$ from the central plane of the tooth. After the first cut, half of this block section was kept for scanning electron microscopy (SEM).

3. The other half of the block was sectioned a second time to create a "thin" section. The cut was taken 900 $\mu \mathrm{m}(500 \mu \mathrm{m}+$ the thickness of the blade) away from the first section plane towards the attached side of the tooth. This second cut was used for transmitted light microscopy.

Each tooth was sectioned from the tip of the cusp to the apex of the root. The incisors, canines, and premolars were sectioned longitudinally through the radial plane, orientated either buccolingal/palatal or labiolingual/ palatal (Antoine et al., 2009). The molars were sectioned longitudinally via a tangential plane oriented through the tips of both the buccal/labial and lingual/palatal cusps (Antoine et al., 2009).

\section{Preparation of the SEM Blocks}

Once the sectioning was accomplished, the halves kept for SEM analysis were polished using an Engis LTd Kent MK2a polishing machine. The tooth was held onto a $3 \mu \mathrm{m}$ and then a $1 \mu \mathrm{m}$ hard plastic mat fixed to a rotating metal plate covered in $3 \mu \mathrm{m}$ or $1 \mu \mathrm{m}$ diamond polishing compound (Metadi II) and sprayed with dilap fluid as a lubricant (adapted from Hillson, 1986). 


\section{Preparation of Thin Sections}

The thin sections were created to view the cementum layers under transmitted and polarized light microscopy. Each thin section was polished using a Lapping Machine Logitech Ltd. PM2 (after Antoine, 2001, 2009).

1. Thin sections were temporarily fixed to glass slides with a thin layer of melted removable sticky wax (Detrey Model Cementum Dental Sticky Wax), vacuumheld to a jig (Logitech PP5GT), and lapped down (approximately $50 \mu \mathrm{m}$ to remove scratches or marks from the sectioning process); a $3 \mu \mathrm{m}$ aluminium oxide abrasive solution was used as a lubricant-abrasive.

2. The polished portion of the tooth was desiccated in silica gel for 30 minutes, permanently mounted to another glass slide using photopolymeric cyanoacrylate resin (Logitech UV resin 358), and exposed to UV light for 30 minutes.

\section{Polishing Thin Sections}

Once one side of a thin section had been mounted to a glass slide, the other surface of the specimens could be polished.

1. Each specimen was polished on abrasive paper with finer grades of 600 and 1200, using deionized water as a lubricant. A glass plate with $3 \mu \mathrm{m}$ aluminium oxide abrasive solution as the lubricant was used for the final polish to remove scratch marks.

2. Each specimen was polished down progressively to $400,300,200$, and $100 \mu \mathrm{m}$, and the appearance of the cementum layers was recorded at each thickness to determine the impact this may have on their observability.

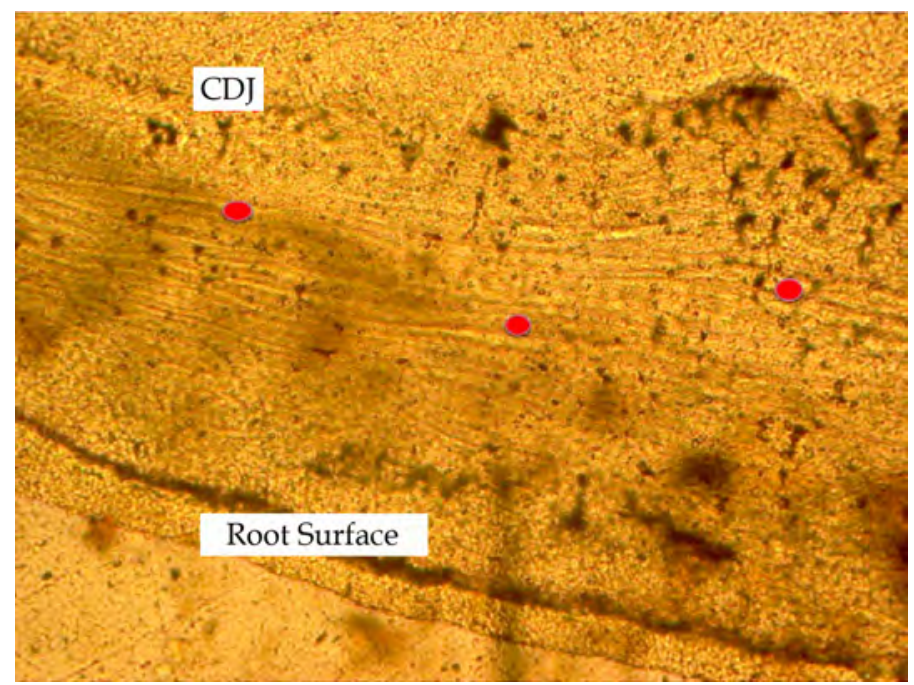

Fig. 1: This is an illustration of cementum layers. The cementum-dentine junction (CDJ) is to the top; the root surface is to the bottom. Each red dot identifies one clearly identifiable cementum layer.

\section{Procedure for Counting the Incremental Layers}

1. Two pictures from each progressive thickness were taken from each tooth. Using digital images, the Granular Layer of Tomes (GLT) was located, a feature that is normally found near the end of the dentine and close to the CDJ.

2. The CDJ initiates where the cementum layers begin. Cementum layer counts were recorded from the CDJ to the root surface or the last preserved cementum layer (Fig. 1).

3. The root was scanned and the clearest areas of dental cementum were selected for analysis (cervical, middle, or apical). One layer was defined from the border of two parallel darker lines. If the layers were difficult to find, the one layer was followed to another region where the increments were clear. If layers were not definable, pictures were taken to indicate no layering. In addition, if only a few layers were visible within the cementum thickness and large areas depicted no clear increments, the specimen was labeled as not having recordable layers.

4. Each of the images for the individuals was counted on three separate occasions, to create an estimated age. Age was calculated by adding the age of eruption of the tooth to the average count of cementum layers, using the Schour and Massler (1941) dental chart. The images and protocol for recording the layers were given to a colleague to count in order to assess interobserver error.

\section{Variability in layer counts}

Using the digitized images from transmitted light microscopy and from the SEM, cementum layers were counted, age of eruption was then combined with the layer count to calculate chronological age. Age ranges for each of the three individuals were then compared with the age ranges from the pubic symphysis (Brooks and Suchey 1990) and auricular surface (Lovejoy et al. 1985).

The interobserver error was tested on a subset of 9 randomly chosen images. The layers were counted twice

Table 2. Interobserver error for cementum layer counts

\begin{tabular}{|c|c|c|}
\hline Specimen & $\begin{array}{c}\text { Layer } \\
\text { count, } \\
\text { colleague }\end{array}$ & $\begin{array}{l}\text { Layer } \\
\text { count, } \\
\text { author }\end{array}$ \\
\hline 1408 LRM2 $400 \mu \mathrm{m}$ & 63 & 24 \\
\hline 1408 URC $400 \mu \mathrm{m}$ & 29 & 31 \\
\hline 1408 URP3 $300 \mu \mathrm{m}$ & 16 & 20 \\
\hline 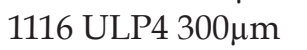 & 17 & 14 \\
\hline 1519 URP3 $200 \mu \mathrm{m}$ & 42 & 20 \\
\hline 1519 URP3 $200 \mu \mathrm{m}$ & 23 & 20 \\
\hline 1116 URC $200 \mu \mathrm{m}$ & 53 & 32 \\
\hline 1116 ULP4 100 $\mu \mathrm{m}$ & 0 & 0 \\
\hline 1116 LRM1 100 $\mu \mathrm{m}$ & 15 & 19 \\
\hline
\end{tabular}



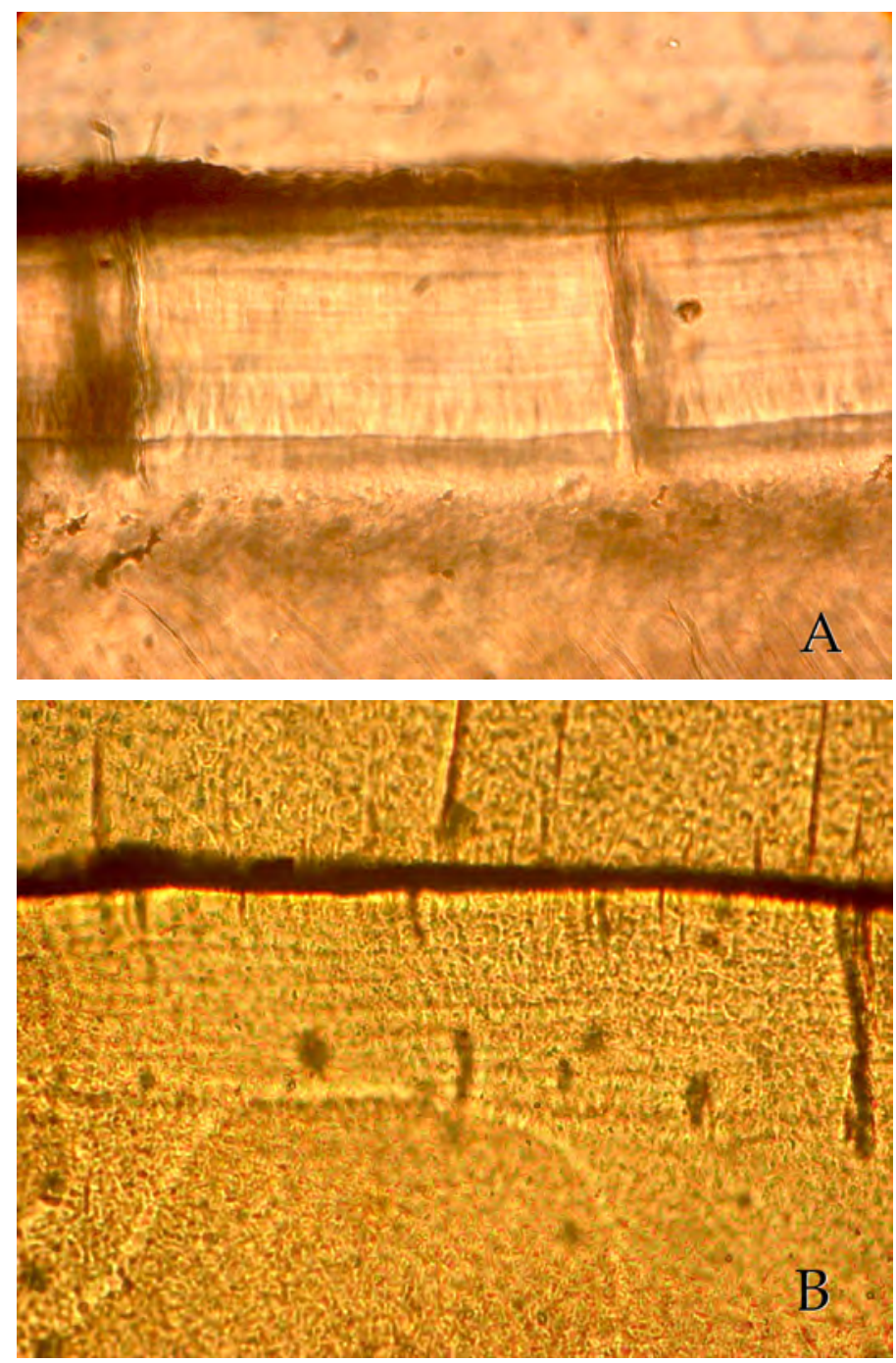

Fig. 2. Interobserver error of cement layer observations between author and colleague. $(A)$ This is a transmitted light microscopy image of cementum layers on an upper right canine at $400 \mu \mathrm{m}$ thickness. The author observed 31 layers, while a colleague observed 29 layers. (B) A transmitted light microscopy image of cementum layers on a lower right first molar at a $100 \mu \mathrm{m}$ thickness. The author observed 19 layers, while a colleague observed 15 layers.

TABLE 3. Visible layers present by region of root

\begin{tabular}{ccccc}
\hline $\begin{array}{c}\text { Region } \\
\text { of } \\
\text { root }\end{array}$ & $\begin{array}{c}\text { No. of } \\
\text { images not } \\
\text { available }\end{array}$ & $\mathrm{n}$ & $\begin{array}{c}\text { Images } \\
\text { of visible } \\
\text { layers }\end{array}$ & $\begin{array}{c}\% \text { of } \\
\text { visible } \\
\text { layers }\end{array}$ \\
\hline Cervical & 7 & 29 & 6 & 0.21 \\
Middle & 7 & 29 & 5 & 0.17 \\
Apical & 7 & 29 & 15 & 0.52 \\
\hline
\end{tabular}

TABLE 4. Visible layers by section thickness and region of root

\begin{tabular}{cccc}
\hline $\begin{array}{c}\text { Section } \\
\text { thickness }\end{array}$ & $\begin{array}{c}\text { Cervical } \\
\text { region }\end{array}$ & $\begin{array}{c}\text { Middle } \\
\text { region }\end{array}$ & $\begin{array}{c}\text { Apical } \\
\text { region }\end{array}$ \\
\hline $100 \mu \mathrm{m}$ & 0.00 & 0.25 & 0.63 \\
$200 \mu \mathrm{m}$ & 0.14 & 0.29 & 0.57 \\
$300 \mu \mathrm{m}$ & 0.50 & 0.00 & 0.50 \\
$400 \mu \mathrm{m}$ & 0.25 & 0.13 & 0.38 \\
\hline
\end{tabular}

per image via a high definition computer screen at high magnification, and then compared with the author's previous counts.

\section{RESULTS}

\section{Aging using Standard Skeletal Methods}

The 3 individuals were aged in the traditional methods of skeletal aging using the pubic symphysis and auricular surface. Individual 1519 was the youngest of the three skeletons, determined to be 20-24 years of age. The second individual, 1116, was estimated to be between 35-39 years. Specimen 1408 was the oldest of the three and was assessed to be 50-60 years (Lovejoy et al., 1985).

The interoberver error indicated that the layer counts were similar although there were differences for some specimens (Table 2). The minimum difference between cementum counts was 0 and the maximum difference was 39. These results indicate that the process of counting cementum layers, even with a specific definition outlining the features constituting an increment, has a level of subjectivity (Fig. 2).

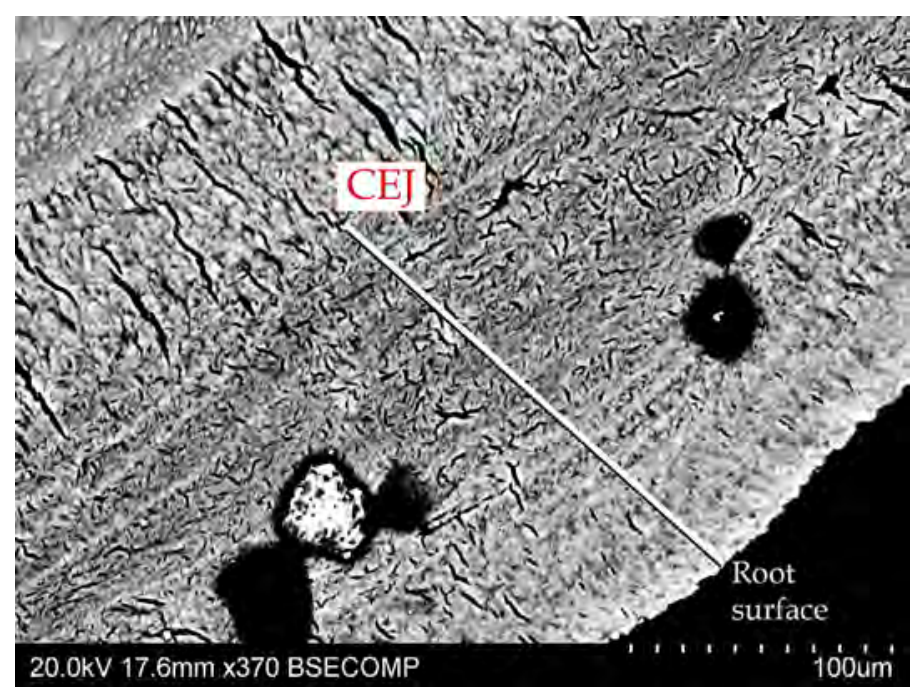

Fig. 3. Scanning electron microscopy (SEM) image depicting poorly defined cementum layering. The white line indicates the length of the cement layers. Most SEM blocks showed very few layers due to cracks affecting the imaging. 
TABLE 5. Average counts of cementum layering for each specimen with eruption age compared with skeletal age estimate using the auricular surface ${ }^{\dagger}$

\begin{tabular}{ccc}
\hline Specimen & $\begin{array}{c}\text { Cementum } \\
\text { layer age range }\end{array}$ & $\begin{array}{c}\text { Skeletal } \\
\text { age range }\end{array}$ \\
\hline 1116 & $27-37$ & $35-39$ \\
1519 & $24-43$ & $20-24$ \\
1408 & $33-35$ & $50-60+$ \\
\hline
\end{tabular}

${ }^{\dagger}$ Eruption age of each tooth specimen was totaled with averaged cementum layer count to compile age ranges.

All regions of the root (cervical, middle, apical) were viewed in order to assess and count all cementum layers. The apical region of the root indicated the clearest area for observing and counting cementum layers (Tables 3-4).

When using SEM imaging, cementum layers were not visible in the majority of the specimens (Fig. 3). Transmitted light microscopy was found to be optimal for observing the cementum layers. Section thicknesses of $200 \mu \mathrm{m}$ to $300 \mu \mathrm{m}$ viewed under transmitted light microscopy showed the clearest cementum layers. The apical region of the root showed the clearest images of visible cementum layering in the majority of specimens. In general, the upper right third premolar consistently exhibited cementum layering.

This study found cementum layers tend to overestimate age in the younger individual, concurring with other studies (Miller et al., 1988; Kvaal and Solheim, 1995; Meinl et al., 2008). The present study found cementum layers to underestimate the older individuals in accord with other research (Miller et al., 1988; Kvaal and Solheim, 1995; Meinl et al., 2008). Overall, many ranges of cementum layer counts were found for each individual. For example, layer counts for individual 1116 specimen LRM1 at $400 \mu \mathrm{m}$ ranged from 20-30, and at $300 \mu \mathrm{m}$ 12-16 layers were identified. When the eruption age was added to these increments variable age ranges were found per each individual (Table 5).

\section{DISCUSSION}

Skeletal The appreciable between-observer differences reflect how difficult recording cementum structures can be. When the interobserver results were combined, the cementum age estimates were very large (Table 6). The

Table 6. Age range for each individual

\begin{tabular}{cccc}
\hline Specimen & $\begin{array}{c}\text { Cementum } \\
\text { Layer Age } \\
\text { Range }\end{array}$ & $\begin{array}{c}\text { Cementum } \\
\text { and Combined } \\
\text { Interobserver } \\
\text { Age Range }\end{array}$ & $\begin{array}{c}\text { Skeletal } \\
\text { Age } \\
\text { Range }\end{array}$ \\
\hline 1519 & $24-43$ & $24-52$ & $20-24$ \\
1116 & $27-37$ & $21-64$ & $35-39$ \\
1408 & $33-35$ & $26-75$ & $50-60+$ \\
\hline
\end{tabular}

cementum layer estimates did not compare well with the pelvis age ranges. Overall, he observation and recording of cementum layers has proven to be difficult.

The apical region of the root proved to be the best area to observe and count cementum layers. Cementum layers in the cervical and middle regions of the root were markedly unclear and nearly incalculable in the majority of sections. Perhaps diagenetic processes or the sectioning technique rendered these regions of cementum unusable.

Counting cementum layers as an estimate of the age-of-death resulted in a broad range of age estimates. Unfortunately, the accuracy of cementum layering for aging individuals in the present study cannot be compared to other studies, in part because the skeletal specimens were of unknown age.

Many of the research studies have used modern teeth (Zander and Hurzeler, 1958; Charles et al., 1986; Kvaal et al., 1996; Renz and Radlanski, 2006); only a few have actually used archaeological specimens (Lieberman, 1994; Jankauskas et al., 2001; Wittwer-Backofen et al., 2008; Roksandic et al., 2009). As previously observed by Lieberman, using archaeological specimens to observe incremental layers can be problematic: unidentified diagenetic processes may affect the optical properties of the cementum with the dissolution of collagen reducing the number of visible layers and microbial action removing outer layers (Lieberman, 1994). Indeed, chemical diagenic processes such as collagen leaching (removal of collagen through water or other liquids) and apatite recrystallization (development of banded features that mimic cementum layers) can both dissolve layers or create extra bands, affecting the technique's accuracy (Stutz, 2002). The integrity of the dental cementum can also be compromised in archaeological specimens. The present study found that the more rapidly growing cellular cementum found at the apex of the root showed the clearest layers, whereas the slower and thinner acellular cementum layers found in the middle and cervical regions were difficult to observe. In their study of the applicability of cementum layers aging in archaeological specimens Roksandic et al. (2009) reported similar problems. Approximately $80 \%$ of the teeth were discarded because the cementum layers appeared to be compromised by diagenic processes causing wavy lines that were interspersed with pits, impurities bifurcating lines, and partially obscured lines (Roksandic et al., 2009). They also found that the cervical and middle regions of the cementum were the most difficult to record and most likely affected by diagenic processes.

The present study found that, in archaeological material, the observation of cementum layers can be difficult, and there is variability in the readability of various regions of the root, possibly caused by diagenic processes. Evaluating and understanding the variables that may affect the observability of archaeological cementum layers should be a prerequisite to assessing how useful cementum layers are in estimating biological 
age. Unfortunately for archaeologists, the growth structures in the cementum of ancient teeth often are difficult to observe. When they are observed, the number of visible layers can be affected by diagenetic processes, compromising their use as an aging technique.

\section{CONCLUSION}

The present study studied incisors, canines, premolars, and molars, cut and polished at progressively thin sections from archaeological specimens of unknown ages. Interobserver error indicated that viewing and counting cementum layers can prove to be a difficult process that can lead to large age ranges per individual. The readable and unreadable segments of the various root regions are disconcerting and can lead to a high level of subjectivity that increases intra- and interobserver error. Chemical diagenetic processes affect the integrity of archaeological dental tissue, often obscuring and/or creating additional layers within the cementum. The current study has found that there are incremental layers within dental cementum that correlate positively with age, although there is little understanding of the significance of these layers. Evaluating archaeological dental material and the variables, such as subjectivity in counts and diagenetic processes, that affect the observability of cementum layers is important. Therefore, to successfully evaluate the aging technique of cementum layers using archaeological material, researchers must understand the problems of observability. Research should focus on understanding the biological process of cementum formation, as well as an examination of how diagenetic processes affect archaeological dental tissue.

\section{ACKNOWLEDGEMENTS}

I want to thank The Museum of London for providing access to their skeletal collections, and Debbie GuatelliSteinberg for her critiques and comments throughout my writing process.

\section{REFERENCES CITED}

Antoine D, Hillson S, Dean MC. 2009. The developmental clock of dental enamel: a test for the periodicity of prism cross striation. J Anat 214:45-55.

Antoine D. 2001. Evaluating the Periodicity of Incremental Structures in Dental Enamel as a Means of Studying Growth in Children from Past Human Populations. Ph.D. dissertation, University College London.

Bass WM. 2005. Human osteology: a laboratory and field manual. Columbia, Missouri: Missouri Archaeological Society.

Beasley MJ, Brown WAB, Legge AJ. 1992. Incremental banding in dental cementum: methods of preparation for teeth from archaeological sites and for modern comparative specimens. Int J Osteoarch 2:37-50.
Bosshardt DD, Schroeder HE. 1991. Initiation of acellular extrinsic fiber cementum on human teeth. Cell Tissue Res 263:311-324.

Brooks ST, Suchey JM. 1990. Skeletal age determination based on the os pubis: A comparison of the AcsádiNemeskéri and Suchey-Brooks methods. Hum Evol 5:227-238.

Charles DK, Condon K, Cheverud JM, Buikstra JE. 1986. Cementum annulation and age determination in Homo sapiens: I. tooth variability and observer error. Am J Phys Anthropol 71:311-320.

Condon K, Charles DK, Cheverud JM, Buikstra JE. 1986. Cementum annulation and age determination in Homo sapiens: II. estimates and accuracy. Am J Phys Anthropol 71:321-330.

Hillson S. 1986. Teeth. Cambridge, England: Cambridge University Press.

Hillson S. 1996. Dental anthropology. Cambridge, England: Cambridge University Press.

Hillson S, Antoine D. 2003. Ancient bones and teeth on the microstructural level. In: Grupe G, Peters J, editors. Deciphering ancient bones-the research potential of bioarchaeological collections. Documenta Archaeobiologiae, Rahden/Westf.: Leidorf. p 141-157. Jankauskas R, Barakauskas S, Bojarun R. 2001. Incremental lines of dental cementum in biological age estimation. Homo 52:59-71.

Jones SJ. 1981. Human tissue: cement. In: Osborn JW, editor. Dental anatomy and embryology. London, England: Blackwell Scientific Publications. p 193-209.

Klevezal GA, Shishlina NI. 2001. Assessment of the season of death of ancient human from cementum annual layers. J Arch Sci 28:481-486.

Kvaal SI, Solheim T. 1995. Incremental lines in human dental cementum in relation to age. Eur J Oral Sci 103:225-230.

Kvaal SI, Solheim T, Bjerketvedt D. 1996. Evaluation of preparation, staining, and microscopic techniques for counting incremental lines in cementum of human teeth. Biotech Histochem 71:165-172.

Lieberman DE. 1994. The biological basis for seasonal increments in dental cementum and their application to archaeological research. J Arch Sci 21:525-539.

Lovejoy CO, Meindl RS, Pryzbeck TR, Mensforth RP. 1985. Chronological metamorphosis of the auricular surface of the ilium: a new method for the determination of age at death. Am J Phys Anthropol 68:15-28.

Maat GJR, Gerretsen RRR, Aarents MJ. 2006. Improving the visibility of tooth cementum annulations by adjustment of the cutting angle of microscopic sections. For Sci Int 159S:S95-S99.

Meinl A, Huber CD, Tangl S, Gruber GM, Teschler-Nicola M, Watzekn G. 2008. Comparison of the validity of three dental methods for the estimation of age at death. For Sci Int 178:96-105. 
Miller CS, Dove SB, Cottone JA. 1988. Failure of use of cemental annulations in teeth to determine the age of humans. J For Sci 33:137-143.

Morris P. 1978. The use of teeth for estimating the age of wild mammals. In: Butler PM, Joysey KA, editors. Development, function and evolution of teeth. London: Academic Press. p 483-494.

Naylor JW, Miller GW, Stokes GN, Stott GG. 1985. Cemental annulation enhancement: a technique for age determination in man. Am J Phys Anthropol 68:197-200.

Perrin WF, Myrick AC. 1980. Growth of odontocetes and sirenians: problems in age determination. Proceedings of the international conference on determining age of Odontocete Ceteans. La Jolla, California, September 5-19, 1978, Report of the International Whaling Commission, Special Issue No. 3, Cambridge: International Whaling Commission.

Renz H, Schaefer V, Duschner H, Radlanski RJ. 1997. Incremental lines in root cementum of human teeth: an approach to their ultrastructural nature by microscopy. Adv Dent Res 11:472-477.

Renz H, Radlanksi RJ. 2006. Incremental lines in root cementum of human teeth - a reliable age marker? Homo 57:29-50.

Roksandic M, Vlak D, Schillaci MA, Voicu D. 2009. Applicability of tooth cementum annulation to an archaeological population. Am J Phys Anthropol 140:583-588.
Scheuer L, Black S. 2000. Developmental juvenile osteology. London, England: Elsevier Academic Press.

Schour I, Massler M. 1941. The development of the human dentition. J Am Dent Assoc 28: 1153-1160.

Solheim T. 1990. Dental cementum apposition as an indicator of age. Scand J Dent Res 98:510-519.

Stamfelj I, Vidmar G, Cvetko G, Gaspersic D. 2008. Cementum thickness in multirooted human molars: a histometric study by light microscopy. Ann Anat 190:129-139.

Stott GG, Sis RF, Levy BM. 1982. Cementum annulation as an age criterion in forensic dentistry. J Dent Res 61:814-817.

Stutz AJ. 2002. Polarizing microscopy identification of chemical diagenesis archaeological cementum. J Arch Sci 29:1327-1347.

Wedel VL. 2007. Determination of season at death using dental cementum increment analysis. J For Sci 52:1-4.

Wittwer-Backofen U, Buckberry J, Czarnetzki A, Doppler S, Grupe G, Hota G, Kemkes A, Larsen CS, Prince D, Wahl JJ, Fabig A, Weise S. 2008. Basics in paleodemography: a comparison of age indicators applied to the early medieval skeletal sample of Lauchheim. Am J Phys Anthropol 123:119-129.

Zander HA, Hurzeler B. 1958. Continuous cementum apposition. J Dent Res 37:1035-1044.

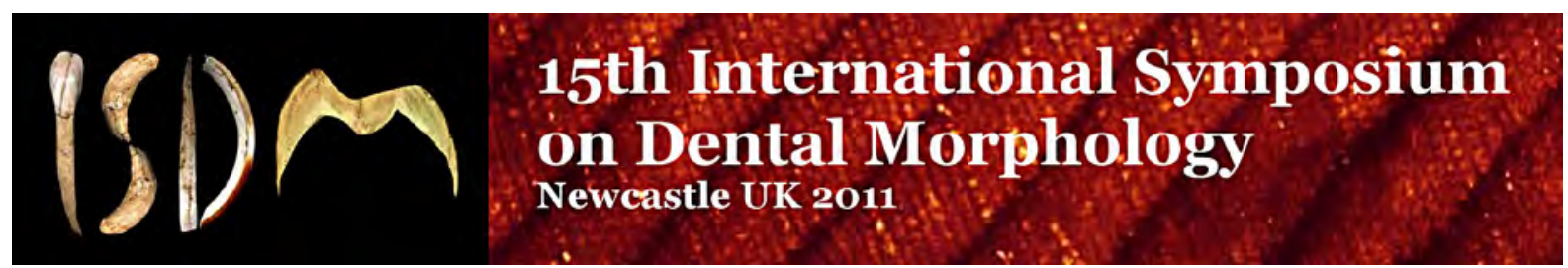

The 15th International Symposium on Dental Morphology will be held from 24-27 August, 2011 at Northumbria University in Newcastle upon Tyne, United Kingdom, sponsored by the Newcastle University School of Dental Sciences. This symposium will bring together scholars from around the world to present research in all aspects of dental morphology. The range of presentations will be broad and include topics such as dental anthropology, dental evolution, dental function, growth and development, dental tissues, and the genetics and clinical aspects of dental morphology. For more information or to be added to our mailing list, please contact Dr Wendy Dirks (Wendy.Dirks@ncl.ac.uk ). 